\title{
The role of ultraviolet radiation in the pathogenesis of pterygia (Review)
}

\author{
WEI-PING ZHOU, YUAN-FANG ZHU, BEI ZHANG, WEN-YA QIU and YU-FENG YAO \\ Department of Ophthalmology, Sir Run Run Shaw Hospital, School of Medicine, \\ Zhejiang University, Hangzhou, Zhejiang 310016, P.R. China
}

Received May 27, 2015; Accepted April 1, 2016

DOI: $10.3892 / \mathrm{mmr} .2016 .5223$

\begin{abstract}
Pterygium is a common ophthalmic disease affecting humans only. Extensive epidemiological data have demonstrated a causative effect of chronic ultraviolet (UV) radiation on pterygia. Progress has been made in determining the origin of pterygia, their nasal predilection and wing-shaped appearance, and the roles of UV radiation in the initiation and the development of pterygia. In the present review, the current understanding of the involvement of UV radiation in the pathogenesis of pterygia is summarized. This involvement includes the alteration of limbal stem cells and fibroblasts that contribute to the initiation of pterygia and the induction of various pro-inflammatory cytokines, growth factors and matrix metalloproteinases that promote the progression of pterygia. Further elucidation of the roles of UV radiation in the pathogenesis of pterygia may help to encourage individuals at
\end{abstract}

Correspondence to: Professor Yu-Feng Yao, Department of Ophthalmology, Sir Run Run Shaw Hospital, School of Medicine, Zhejiang University, 3 Qingchun Road East, Hangzhou, Zhejiang 310016, P.R. China

E-mail: yaoyufrrsh@sina.com

Abbreviations: LSCs, limbal stem cells; EGFR, epidermal growth factor receptor; MMPs, matrix metalloproteinases; MAPK, mitogen-activated protein kinase; ECM, extracellular matrix; $\mathrm{NF}-\kappa \mathrm{B}$, nuclear factor- $\kappa \mathrm{B}$; cAMP, cyclic adenosine monophosphate; TIMP, tissue inhibitor of matrix metalloproteinases; CREB, cAMP response element-binding protein; HB-EGF, heparin-binding epidermal growth factor; CYP1A1, cytochrome P450 1A1; PDGF, platelet-derived growth factor; PLD, phospholipase D; VEGF, vascular endothelial cell growth factor; PECs, pterygium epithelial cells; HIF $\alpha$, hypoxia-inducible factor $\alpha$; TGF- $\beta$, transforming growth factor- $\beta$; AIG, anchorage-independent growth; b-FGF, basic fibroblast growth factor; SP, substance P; TNF- $\alpha$, tumor necrosis factor- $\alpha$; PEDF, pigment epithelium-derived factor; PDGFR, platelet-derived growth factor receptor; 3'-UTR, 3'-untranslated region; ERK, extracellular signal-regulated kinase; MT-MMPs, membrane-type MMPs; JNK, c-Jun amino-terminal kinase

Key words: pterygia, pterygium, ultraviolet radiation, limbal stem cells, pterygium cells, cytokines, growth factors, matrix metalloproteinases risk of developing pterygia to take preventive measures and aid researchers in the development of novel targeted therapeutic agents to treat pterygia.

\section{Contents}

1. Introduction

2. The involvement of ultraviolet radiation in the initiation of pterygia

3. The involvement of ultraviolet radiation in the development of pterygia

4. Discussion

\section{Introduction}

Clinically, pterygium is an ocular surface disorder that exhibits a wing-like shape and a preference for the nasal limbus. Pterygium hinders eyesight and affects cosmetic appearance. Histopathologically, pterygium is characterized by the centripetal growth of a cluster of altered limbal stem cells (LSCs) followed by squamous metaplastic and goblet cell hyperplastic epithelium, Bowman's membrane dissolution accompanied by abundant active fibroblasts, a proliferative stroma with inflammation, neovascularization and extracellular matrix (ECM) (1). Previous studies have indicated that pterygium is associated with numerous risk factors, including ultraviolet (UV) radiation (2-5), viral infection (6-8), hereditary factors (9-11), immunological factors (12), aseptic inflammation (13), environmental irritation from wind, dust or trauma, smoke and ocular dryness (14). Recently, increased levels of the transcription factors cAMP response element-binding protein (15), cytochrome P450 1A1 protein (16), phospholipase D (17), and aquaporin-1 and -3 (18) have been implicated as risk factors for pterygia development. UV radiation remains a well-established pathogenic factor of pterygium based on epidemiological evidence (19-21). Pterygium is more commonly observed in populations in regions between the latitudes of $40^{\circ}$ north and south of the equator, known as the 'pterygium zone,' associated with the higher UV intensity in this region. The prevalence rate of pterygium within this region was estimated to be up to $22 \%$ (22), and $<2 \%$ outside it (2), implying that UV radiation may be associated with 


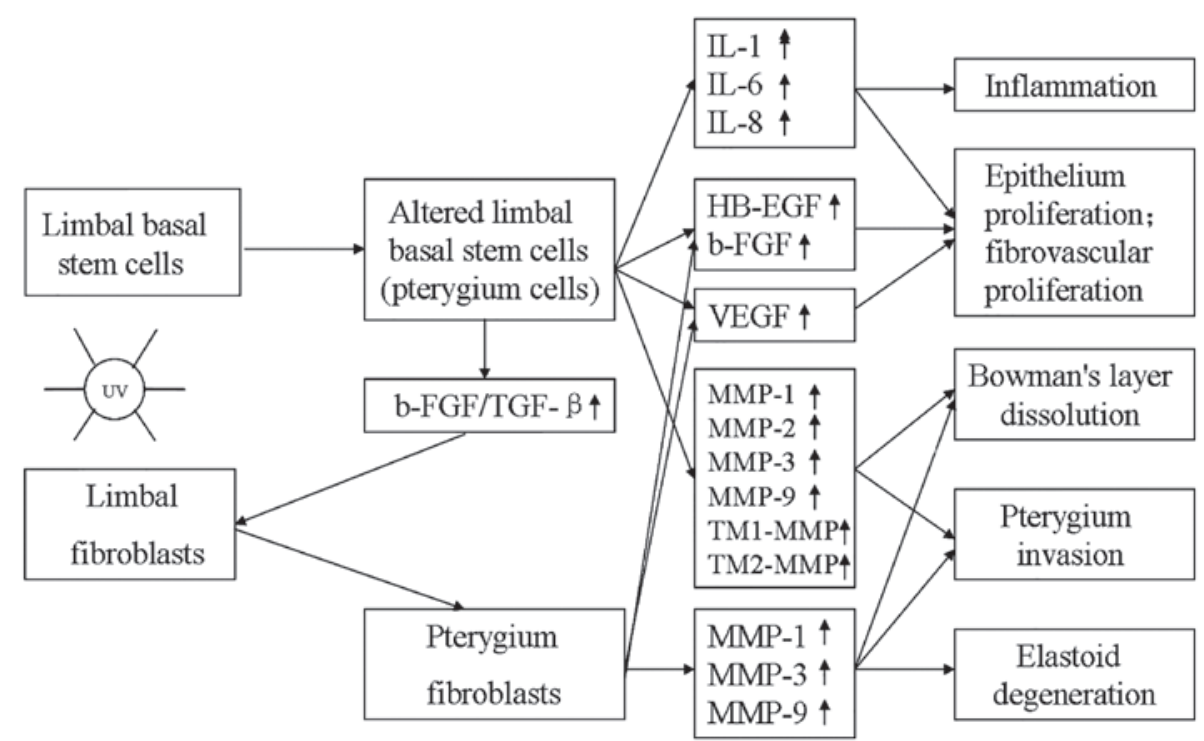

Figure 1. Potential roles of UV radiation in the pathogenesis of pterygium. UV radiation-mediated alteration of limbal stem cells serves to initiate pterygium. Pterygium cells expressing elevated levels of numerous inflammatory cytokines, growth factors and MMPs contribute to the inflammation, fibrogenesis, and vascularization and invasion of pterygium. Limbal fibroblasts activated by UV radiation or by pterygium cells in a b-FGF/TGF- $\beta$-dependent manner, produce increased levels of multiple growth factors and MMPs, which contribute to the extracellular matrix remodeling and dissolution of Bowman's membrane and the invasion of pterygium. UV, ultraviolet; IL, interleukin; HB-EGF, heparin-binding epidermal growth factor; b-FGF, basic fibroblast growth factor; VEGF, vascular endothelial cell growth factor; MMP, matrix metalloproteinase; TGF- $\beta$, transforming growth factor- $\beta$.

the pathogenesis of pterygium. In addition, the UV theory is supported by the histopathological characteristics of pterygium that are similar to UV-damaged skin (23), and that focal limbal radiation may explain the nasal predisposition and the shape of pterygia $(24,25)$. Chronic UV exposure results in an increase of $\geq 20$-fold in incident light at the nasal limbus, rendering LSCs more vulnerable and gradually resulting in focal limbal failure, which has been considered as a trigger for pterygium $(14,26)$. However, a recent study indicated no association between the LSC damage and the pterygium occurrence (27), although its conclusion should be interpreted with caution due to race and sample size limitations.

A two-stage hypothesis has been proposed in the present review to explain the pathological process of pterygium. First, focal LSCs are altered gradually by chronic UV radiation, which serves as the initiation of pterygium. Then, the progressive 'conjunctivalization' of the cornea occurs due to focal limbal barrier dysfunction. In addition to involvement in the initiation of pterygium, UV radiation has been implicated in the progression of pterygium via the upregulation of multiple pro-inflammatory cytokines, growth factors and matrix metalloproteinases (MMPs). These effectors are important in the inflammation, fibrosis, angiogenesis and ECM remodeling, which characterize pterygium (Fig. 1). The molecular mechanism underlying the potential role of UV radiation in the initiation and the development of pterygium will then be investigated in the current review.

The biological effects of $U V$ radiation. UV radiation from sunlight is separated into 3 categories, as follows: UVA (wavelength, 320-400 nm), UVB (wavelength, 280-320 nm) and UVC (wavelength, 200-280 $\mathrm{nm}$ ). UVA has the longest wavelength and the maximum penetration power, thus it is not attenuated by the ozone layer and comprises $90-99 \%$ of UV radiation. UVA is an important inducer of pigmentation and contributes to the premature aging of the skin, immunosuppression and carcinogenesis. By contrast to UVA, UVB is absorbed by the ozone layer and it comprises $\sim 1-10 \%$ of the total UV radiation that reaches the earth's surface. UVB acts as an erythema inducer and it is, similarly to UVA, responsible for various biological events, including sunburn, immunosuppression and carcinogenesis. UVC has the highest energy of the three UV rays, and it possesses strong mutagenic properties and may result in erythematous reaction. UVC is almost completely absorbed by the ozone layer. Thus, solar UVC radiation imposes negligible effects to human eyes (28).

UV (UVA and B) radiation have been implicated in numerous biological effects, including DNA damage (29), oxidative stress (30), and cell surface receptor and intracellular signaling pathway activation (31-34). These effects are closely associated with alteration of the transcriptional profile of multiple genes and, thus, changes in the biological behavior of cells. The effects of UV radiation have been widely detected in pterygia ex vivo and in pterygium epithelial cells (PECs) in vitro (35-42), implying that UV radiation may be involved in the pathogenesis of pterygium via its biological effects on ocular cells, including LSCs.

\section{The involvement of $U V$ radiation in the initiation of pte- rygia}

The alteration of LSCs has been increasingly recognized as the initial biological event in the formation of pterygium. Incident UV radiation at the temporal limbus has been demonstrated to focus at the nasal limbus (Fig. 2), and damage LSCs and fibroblasts residing at the nasal limbus. These altered LSCs (pterygium cells) migrate centripetally towards the cornea to form a migratory limbus, and a certain number of these cells 


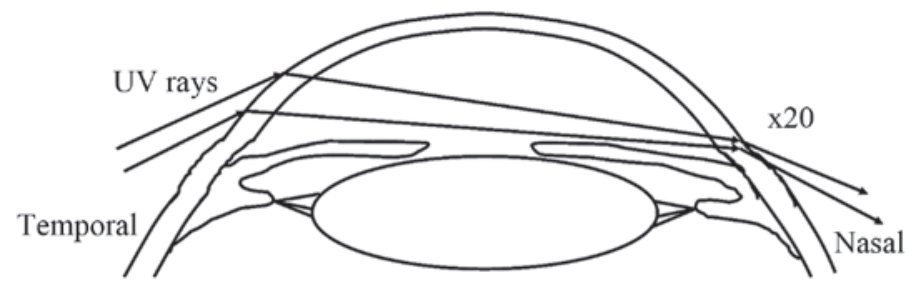

Figure 2. Proposed travel pathway of UV rays in the anterior segment. UV rays incident at the temporal cornea transverse the anterior chamber and focus at the nasal limbus resulting in peak light intensity at the nasal limbus 20 -fold greater than the incident light intensity. UV, ultraviolet.

infiltrate the circumferential limbal and local conjunctival epithelia (43), which may result in an increased recurrence rate if all invading pterygium cells are not removed. The breakdown of the focal limbal barrier facilitates the encroachment of conjunctival epithelial cells into the cornea.

The identification of pterygium cells. Conventionally, pterygium was considered to be the result of the ingrowth of fibroblasts from the limbal connective tissue into the adjacent cornea (4). However, subsequent to the discovery of the LSCs, researchers hypothesized abnormal limbal barriers resulting from UV radiation may contribute to the initiation of pterygia $(25,44,45)$. Dushku et al $(43)$ proposed that pterygia arise from altered limbal epithelial basal cells exhibited a migratory phenotype. These abnormal LSCs were designated pterygium cells and investigated in numerous subsequent studies $(46,47)$. Although the origin of pterygium cells has been confirmed via immunohistochemistry, further research is ongoing (48-50). Pterygium cells were initially described by Fuchs (51) over a century ago. Morphologically, the clustered cells in the basal epithelia of the pterygium are smaller, primitive and less differentiated. In addition, these cell clusters are clinically termed Fuchs' flecks, and may be visualized using a slit-lamp and confocal microscopy (50).

$U V$ radiation-mediated formation of pterygium cells. The human eye receives UV rays directly from sunlight, and scattered or reflected from the surface of objects outdoors or indoors. Human eyes are exposed laterally, allowing for a large temporal visual field and permitting more light to reach the temporal anterior segment. Incident light at the temporal limbus transverses the anterior chamber and ultimately converges at the nasal limbus via peripheral off-axis refraction. Employing computer-assisted optical ray tracing techniques, Kwok and Coroneo (24) and Coroneo (25) calculated that the peak light intensity may be concentrated by up to 20 -fold at the distal limbus. UV light has, in addition to visible light, been shown to act similarly $(14,26,52)$. Focal UV radiation reaches nasal LSCs in the basal layer of the limbus via a transcameral path (48). Without the protection of superficial cells, the focal LSCs at the nasal limbus may become dysfunctional or be depleted. Based on the identification of pterygium cells in the pterygia epithelia, researchers have hypothesized that focal UV radiation may alter or activate, rather than destroy LSCs (50). The effects of focal UV radiation on LSCs requires be further elucidation, as they are associated with the initiation of pterygia. Based on the immunomodulatory effects of UV radiation on other cell types, Kwok and Coroneo (24) proposed that chronic focal UV radiation may ultimately alter the LSCs via similar mechanism. However, this remains to be confirmed experimentally. Reid and Dushku (48) suggested that UV radiation-induced p53 gene mutations may be involved in the development of pterygium cells, as they detected abnormal p53 protein expression levels in the basal cells of the pterygia epithelium via immunohistochemical staining. According to this hypothesis, p53 mutations occur in the parental basal LSCs under chronic focal UV radiation exposure. Due to the deficiency of p53-dependent programmed cell death, mutations in other genes are progressively acquired by altered LSCs, which ultimately evolve into pterygium cells (48). The p53 gene is a known tumor suppressor gene and its protein product acts as a checkpoint by preventing cell proliferation or inducing apoptosis in response to DNA damage resulting from certain mutagenic agents, including UVB radiation (53-55). Under normal conditions, the $\mathrm{p} 53$ protein has a short half-life of $<30 \mathrm{~min}$ and is often undetectable in the cell (48). Mutations in the p53 gene are considered to result in the accumulation of an abnormal p53 protein that has a longer half-life of several hours (56), enabling its detection. Previous studies have demonstrated increased p53 protein levels in the pterygium basal epithelium (57-59). However, other studies indicated that there is no p53 protein expression in the pterygium cells $(60,61)$, disputing the importance of p53 mutations in the formation of these cells. Furthermore, recent DNA sequencing analysis of the p53 gene demonstrated no mutations in the pterygium basal epithelium $(62,63)$, indicating the weakness of the hypothesis that p53 mutations contribute to the formation of the pterygium cells. These discrepancies may be due to methodological differences, or they may reflect a normal response to UV exposure (28), as it has been demonstrated that UV radiation stabilizes p53 via post-transcriptional mechanisms. The latter possibility may partially explain the increased level of p53 in the pterygium cells. Alternatively, the overexpression of p53 suggests the certain proteins involved in the regulation of p53 protein activity or catabolism have been abnormally altered. The role of p53 in the formation of pterygium cells and the role of UV radiation in the induction of pterygium cells remain to be elucidated.

UV radiation-mediated activation of limbal fibroblasts. Activated fibroblasts with an invasive nature have been described in the pterygium stroma and classified into four groups according to their location in pterygia (47). Pterygium fibroblasts exhibit lower serum and exogenous growth factor requirements, and a higher saturating cell density than conjunctival fibroblasts under the same culture conditions. 
Table I. Distribution and expression of inflammatory cytokines in pterygia.

\begin{tabular}{|c|c|c|c|c|c|}
\hline $\begin{array}{l}\text { First author, year } \\
\text { Refs. }\end{array}$ & Cytokine & Distribution in pterygia & Expression & UV inducibility & \\
\hline $\begin{array}{l}\text { Wen, } 2003 \\
\text { Kennedy, } 1997 \\
\text { Krämer, } 1993\end{array}$ & IL-1 & Epithelium & $\uparrow^{a}$ & Yes & $\begin{array}{l}(74) \\
(77) \\
(78)\end{array}$ \\
\hline $\begin{array}{l}\text { Di Girolamo, } 2006 \\
\text { Di Girolamo, } 2002\end{array}$ & IL-6 & Epithelium & $\uparrow^{b}$ & Yes & $\begin{array}{l}(42) \\
(75)\end{array}$ \\
\hline $\begin{array}{l}\text { Di Girolamo, } 2006 \\
\text { Di Girolamo, } 2002\end{array}$ & IL-8 & Epithelium, vasculature & $\uparrow^{b}$ & Yes & $\begin{array}{l}(42) \\
(75)\end{array}$ \\
\hline $\begin{array}{l}\text { Kria, } 1996 \\
\text { Bazzoni, } 1994\end{array}$ & TNF- $\alpha$ & Epithelium, vasculature, fibroblasts & $\downarrow^{\mathrm{b}}$ & Yes & $\begin{array}{l}(76) \\
(79)\end{array}$ \\
\hline
\end{tabular}

In addition, pterygium fibroblasts, but not conjunctival fibroblasts, exhibit colony formation ability in soft agar (64). These results indicate that pterygium fibroblasts have a transformed phenotype. UV radiation was demonstrated to induce multiple DNA alterations in pterygium fibroblasts (4), implying that UV radiation may be responsible for their abnormal biological behavior. Cameron (65) identified active fibroblasts with elongated nuclei and numerous irregular nuclear pores under an electron microscope and subsequently hypothesized that focal UV radiation activates fibroblasts residing in the limbal subepithelial connective tissue. Subsequent to these results, Reid and Dushku (48) hypothesized that UV radiation-altered LSCs may activate normal fibroblasts via a transforming growth factor- $\beta$ (TGF- $\beta$ )-fibroblast growth factor (b-FGF)-dependent mechanism, which was postulated to lead to abnormal fibroblast phenotypes and growth characteristics. In addition, Lemercier et al (66) proposed that chronic UV radiation may damage pericorneal conjunctival endothelial cells, which in turn disturbed the metabolism of fibroblasts, resulting in the alteration of their expression pattern in collagen and elastic fibers. Although UV radiation appears to be a major factor that promotes the formation of pterygium fibroblasts, there are different opinions regarding this issue (1,67-69). These hypotheses challenge the importance of UV radiation to the development of pterygium fibroblasts. Further investigation is required to elucidate the role of UV radiation in the formation of pterygium fibroblasts.

The nasal predilection and wing-shaped appearance of pterygia. It is well known that LSCs are crucial in maintaining the limbal barrier between the cornea and the conjunctiva. Chronic focal UV radiation-mediated alterations in nasal LSCs may result in a failure of the limbal barrier, providing a sound explanation for the nasal predisposition of pterygium. Prior attempts into explaining the wing shape of pterygia have been made. The earliest hypothesis was proposed by Arlt that the fold of conjunctiva is pulled over the cornea by the inward encroachment of an ulcer at the tip of the fold, however this hypothesis was refuted by Fuchs $(24,51)$. The finding that UV radiation converges at the nasal limbus, enabled scientists to consider the role of UV radiation in the shape of pterygia. Based on the findings that the light intensity peaks at the zero azimuth position and that the zone of focused light extends circumferentially for a distance of $\pm 1.6 \mathrm{~mm}$ (14), Kwok and Coroneo (24) predicted a wing-shaped appearance and a horizontal orientation of pterygia using a population balance model of epithelial cells in the cornea and the limbus. The degree of limbal light focusing is determined by the corneal shape and the anterior chamber depth (26). Steeper corneas have higher peak intensity and conversely, flatter corneas have lower peak intensity (70). Thus, individuals with corneas capable of developing intense limbal foci may have a predisposition to develop pterygium. If the above hypothesis is accurate, it may explain the reason that only certain individuals in common environments develop pterygium. This will further aid the ophthalmologists in identification of individuals who are at risk of developing pterygium so that appropriate preventative measures, including wearing sunglasses are recommended.

\section{The involvement of $U V$ radiation in the development of pterygia}

Inflammation. Inflammation is one of the common manifestations of pterygium, and the persistent presence of chronic inflammation is likely required for the development of this condition. As has been described by a number of histologists, the inflammatory cells that infiltrate the pterygium epithelium and matrix include neutrophils (50), mast cells $(71,72)$, lymphocytes and plasma cells (73). Although the inflammatory manifestation of pterygium has been extensively recorded, the precise mechanisms underlying this inflammation require further elucidation. Numerous classic inflammatory factors, including interleukin (IL)-1, -6 and -8, have been demonstrated to be overexpressed in pterygia samples (Table I), which may partly explain the presence of inflammatory infiltrates in pterygia. To further characterize the role of UV radiation in the inflammatory progression of pterygia, efforts have been made to investigate the association 
between abnormal expression of inflammatory cytokines and UV radiation.

Potential role of $U V$ radiation in the abnormal expression of cytokines in pterygia. IL-1 (74), IL-6 and IL-8 (75) have been demonstrated to be markedly upregulated in pterygia compared with normal conjunctiva. By contrast, tumor necrosis factor- $\alpha$ (TNF- $\alpha$ ) exhibits weaker immunohistochemical staining at the basement membrane, the vessel endothelium and the pterygium epithelium than corresponding locations in normal conjunctiva (76). UV radiation has been indicated to induce the production of IL-1 in human corneal cells (77) and HeLa cells (78), providing a possible mechanism underlying the upregulation of IL-1 in the pterygium epithelium. However, experiments have been implemented to investigate this effect in pterygia or in cultured pterygium epithelium cells (PECs), thus, further investigation is required. Di Girolamo et al (75) demonstrated that the mRNA and protein expression levels of IL-6 and -8 were induced in PECs following UVB radiation in a time- and dose-dependent manner. Similarly, the elevated protein levels of IL-6 and IL-8 were detected in UVB-treated pterygia compared with non-radiated pterygia in ex vivo (75). It was further demonstrated that platelet-derived growth factor receptor (PDGFR) served as a transmitter of UVB signal in the induction of IL-6 (75). However, it is the epidermal growth factor receptor (EGFR), rather than PDGFR, that was indicated to be involved in transmitting UVB signaling in the induction of IL-8. In addition, the extracellular signal-regulated kinase (ERK) 1/2, c-Jun amino-terminal kinase (JNK) and p38 signaling pathways were responsible for the UVB-induced production of IL- 6 and -8 in cultured PECs, as administration of each corresponding mitogen-activated protein kinase (MAPK) inhibitor markedly suppressed the production of IL-6 and -8 (42). All the above data provide a possible underlying mechanism for the increased expression of IL-6 and -8 in pterygia. Furthermore, the TNF- $\alpha$ promoter contains nuclear factor $-\kappa \mathrm{B}(\mathrm{NF}-\kappa \mathrm{B})$ binding sites (79). Given that UV radiation activates NF- $\kappa \mathrm{B}(80)$ and $\mathrm{NF}-\kappa \mathrm{B}$ has been demonstrated to be activated in pterygia (81), it is hypothesized that TNF- $\alpha$ may be induced by UV radiation in pterygium. However, the low expression levels of TNF- $\alpha$ in pterygia is inconsistent with this hypothesis. Examination of additional representative pterygia samples is required to validate the difference in TNF- $\alpha$ expression between conjunctiva and pterygia.

Potential roles of cytokines in the inflammation of pterygia. IL-1 signaling has been demonstrated to mediate the induction of various pro-inflammatory cytokines, including IL-6 and IL-8 $(82,83)$ and neutrophil chemoattractants (84) in the cornea. Furthermore, IL-1 (in conjunction with TNF- $\alpha$ ) has been demonstrated to induce MMP-1, MMP-2 and tissue inhibitor of MMPs (TIMP)-1 transcription in PECs in culture (85). It is speculated that a similar process may occur in pterygia, and IL-1 may exacerbate inflammation and contribute to ECM remodeling in pterygia via induction of the above-mentioned factors. It is hypothesized that IL-6 may be responsible for the accumulation of neutrophils in pterygia, as this cytokine is involved in neutrophil recruitment via the upregulation of specific chemokines in inflamed corneas (86). Furthermore, it is likely that IL-6 indirectly contributes to the angiogenesis of pterygium tissue, as IL-6 induces vascular endothelial growth factor (VEGF) expression in various cell lines (87). The abnormal expression of IL-8 may be associated with the marked increase in leukocyte infiltration and neutrophil accumulation in the pterygium tissue, as IL-8 exhibits chemotactic activity on lymphocytes and other nonspecific inflammatory cells, and activates neutrophils $(88,89)$. In addition, a previous study demonstrated that IL- 8 is mitogen and chemo-attractant to vascular endothelial cells, and directly induces angiogenesis in experimental corneal pocket models (90). These data suggest that IL-8 may be involved in the formation of new blood vessels in the pterygium tissue. However, the specific roles of IL-1, -6 and -8 in the progression of pterygium remain to be elucidated, thus further research is required to investigate the precise functions of these cytokines in the development of pterygia. Although it is well known that TNF- $\alpha$ serves a role in UV radiation-induced inflammation (91) and mediates neovascularization by inducing VEGF and b-FGF from the vascular endothelium (92), its low expression in the pterygium tissue must be further investigated prior to concluding that TNF- $\alpha$ contributes to this condition.

Proliferation of fibrovascular tissue. Another common histopathological finding in pterygia is fibrovascular proliferation. The increased vascularity within the stroma or the epithelium of pterygium generally consists of arterioles, venules and numerous capillaries (73). In addition, the overgrowth of stroma within the pterygium tissue is characterized by the presence of fibers that take up elastic stain, but differ from normal elastic fibers. Furthermore, the stroma contains an overgrowth of active fibroblasts and excess deposits of heparin sulfate, versican, laminin, fibronectin and typical collagen fibers. These fibers contain $80-90 \%$ type I collagen, 10-20\% type II and a small quantity of type IV (93). This collagen composition is comparable to that of the conjunctiva tissue (94). The mechanism underlying these proliferative changes in the pterygium tissue remains to be adequately explained. A possible explanation is that inflammation induces angiogenic pathways, however, other causes, including UV radiation are likely required for angiogenesis and fibrogenesis. A number of pro-angiogenic and pro-fibrogenic growth factors, including heparin-binding epidermal growth factor (HB-EGF), VEGF, b-FGF, platelet-derived growth factor (PDGF) and TGF- $\beta$, have been indicated to be overexpressed in pterygia (Table II). $\mathrm{UV}$ radiation has been associated with the upregulation of b-FGF, VEGF and HB-EGF (1). The fibrogenic and angiogenic characteristics of HB-EGF, VEGF, b-FGF, PDGF and TGF- $\beta$, further support that UV radiation may be indirectly involved in the fibrovascular proliferation of pterygia.

Potential role of $U V$ radiation in the abnormal expression of growth factors in pterygia. Immunohistochemical evidence has demonstrated stronger staining for HB-EGF (95) and $\operatorname{VEGF}(23,36,96)$ in the pterygium epithelium and vasculature compared with the normal conjunctiva. Furthermore, EGFR, which is considered to be involved in the UV radiation-induced signal transduction, has been reported to be upregulated in pterygia (97). Similarly, the expression levels of PDGF and TGF- $\beta$ have been indicated to be increased in all major cell types of pterygia, including fibroblasts, epithelial, endothelial 
Table II. Distribution and expression of growth factors in pterygia.

UV

First author, year Growth factors Distribution in pterygia

\begin{tabular}{|c|c|c|c|c|c|}
\hline $\begin{array}{l}\text { Di Girolamo, } 2004 \\
\text { Nolan, } 2003\end{array}$ & HB-EGF & Epithelium, vasculature & $\uparrow^{a}$ & Yes & $\begin{array}{l}(23) \\
(95)\end{array}$ \\
\hline Di Girolamo, 2004 & VEGF & Epithelium, fibroblasts, vascular endothelium & $\uparrow^{b}$ & Yes & $(23)$ \\
\hline Di Girolamo, 2006 & & & & & $(42)$ \\
\hline Bianchi, 2012 & & & & & $(96)$ \\
\hline Kria, 1996 & b-FGF & Epithelium, vasculature, fibroblasts, inflammatory cells & $\mathrm{c}$ & Yes & $(76)$ \\
\hline Detorakis, 2009 & & & & & $(98)$ \\
\hline Brenner, 2005 & & & & & $(104)$ \\
\hline Kria, 1996 & TGF- $\beta$ & Epithelium, vasculature, fibroblasts, inflammatory cells & $\uparrow^{b}$ & Yes & $(76)$ \\
\hline Nolan, 2003 & & & & & $(95)$ \\
\hline Kria, 1996 & PDGF & Epithelium, vasculature, fibroblasts, inflammatory cells & $\uparrow^{b}$ & d & $(76)$ \\
\hline
\end{tabular}

Expression levels of growth factors in pterygia are compared with normal conjunctiva, cornea and limbus. Their UV inducibility is denoted by 'Yes' or 'No'. a'Compared with normal conjunctiva, cornea and limbus; 'bompared with normal conjunctiva; ' not settled; 'not studied. UV, ultraviolet; HB-EGF, heparin-binding epidermal growth factor; VEGF, vascular endothelial growth factor; b-FGF, basic fibroblast growth factor; TGF- $\beta$, transforming growth factor- $\beta$; PDGF, platelet-derived growth factor.

and infiltrating inflammatory cells, compared with the normal conjunctiva (76). However, the same research group demonstrated a lower expression level of b-FGF in pterygia compared with the normal conjunctiva (76). By contrast, another study, using a different method, demonstrated increased levels of b-FGF in pterygia (98). Furthermore, b-FGF overexpression has been observed in cultured fibroblasts from pterygia (99). Therefore, further research is required to verify the differential expression of $b$-FGF between pterygia and normal conjunctiva to objectively characterize its role in pterygium. HB-EGF has been indicated to be induced by UVB radiation in cultured PECs (95), providing an explanation for its upregulation in the pterygium epithelium. Similarly, increased levels of VEGF in pterygia may be due to the effects of UVB radiation, as a notable upregulation of the VEGF protein was observed in PECs following UVB exposure. Furthermore, EGFR and PDGFR have been demonstrated to transmit the UVB signal, and ERK1/2, p38 and JNK signaling pathways are involved in the induction of VEGF (42). In addition to the three classical MAPK signaling pathways, EGFR-mediated UV radiation signaling activates the phosphoinositide 3-kinase (PI3)/AKT cascade, resulting in the activation of hypoxia-inducible factor $1 \alpha(\mathrm{HIF}-1 \alpha)$. HIF- $1 \alpha$ targets the VEGF gene and induces its expression (100). Other possible induction mechanisms of VEGF by UV radiation are as follows: i) UV radiation-inducible cytokine TNF- $\alpha$ (92) and IL-21 appear to be involved in the UVB radiation-mediated production of VEGF (101); ii) UVB radiation-induced expression of VEGF is dependent on de novo protein synthesis and may occur via the release of soluble mediators that subsequently activate VEGF expression (102). The induction of b-FGF by UVB exposure has been demonstrated in the opossum cornea (103), keratinocytes and fibroblasts (104), which may support increased expression levels of b-FGF in pterygia compared with the normal conjunctiva. The TGF- $\beta$ upregulation in pterygia may be due to UVB radiation, as an initial cDNA microarray assay indicated the induction of TGF- $\beta 3$ and TGF- $\beta$ receptor (R) III transcription in UVB radiation-exposed PECs (95). However, whether $\mathrm{UV}$ radiation is involved in the induction of other members of the TGF- $\beta$ family in pterygia remains unknown. Gradually increased mRNA levels of TGF- $\beta 1$ and $-\beta 3$ and reduced mRNA levels of TGF- $\beta 2$ have been observed following UV radiation in keratinocytes and dermal cells (105). A previous study demonstrated elevated protein levels of TGF- $\beta 1$ and downregulated levels of membrane receptor, TGF $\beta$ RII, in UV radiation-exposed skin (106). These results suggest that UV radiation exerts complex effects on the TGF- $\beta$ system that may indirectly contribute to the fibrovascular state of pterygium. As for the abnormal expression of PDGF in pterygia, Lemercier et al (66) proposed a hypothesis that UV radiation may harm pterygium vascular endothelial cells, an effect that favors of the release of PDGF. This hypothesis may suggest an underlying mechanism for the differential distribution pattern of PDGF, however it cannot explain the differential expression levels between pterygia and normal conjunctiva. Therefore, further investigation is required to investigate the potential mechanism of the upregulation of PDGF in pterygia.

Potential roles of growth factors in the fibrovascular changes in pterygia. HB-EGF has been indicated to promote angiogenesis (107), stimulate anchorage-independent growth (AIG) and transform cells (108). These effects partially explain the AIG of pterygium fibroblasts in culture. Nolan et al $(95,109)$ demonstrated the proliferative effects of HB-EGF on PECs and fibroblasts, suggesting the potential role of HB-EGF in epithelial hyperplasia and pterygium fibroblast proliferation observed in pterygium. The VEGF family is involved in increasing vascular permeability, angiogenesis and lymphangiogenesis (110), suggesting that elevated expression of VEGF may be involved in neovascularization and inflammation in pterygia. $b$-FGF is considered to be a potent mitogen for various cell types $(111,112)$ and is involved in angiogenesis $(113)$, thus 
it may be important in the development of hyperplastic epithelium, excessive active fibroblasts and neovascularization in pterygia. Previous studies have demonstrated the involvement of TGF- $\beta$ in angiogenesis and fibroblast activation with the production of collagen $(114,115)$. These effects are consistent with the excess collagen and blood vessels in the pterygium stroma. In addition, TGF- $\beta$ has been indicated to stimulate ECM production via specific receptors (116). These results support the hypothesis of Dushku et al (117) who proposed that elevated TGF- $\beta$ levels may contribute to the fibrovascular phenotype of pterygium (117). In previous studies, PDGF has been observed to demonstrate angiogenic activity and the ability to promote fibroblast proliferation. For example, PDGF exhibits a dose-dependent angiogenic effect on chick chorioallantoic membrane in vivo (118), and facilitates cell proliferation, migration and differentiation on rabbit corneal fibroblasts and epithelial cells (119). The results of these studies indicate the potential role of PDGF in the activation of various cell types in pterygia, and in the angiogenesis observed in pterygia.

Other potent effectors. Less common angiogenic factors, including thrombospondin-1 (120) and substance P (SP) (121), have demonstrated increased expression in pterygia, and these factors may promote angiogenesis by activating the transcription factor ETS-1 (122). Furthermore, elevated levels of SP have been detected in tear and plasma samples from patients with pterygium (123). A previous study demonstrated that SP is a potent chemo-attractant on pterygium fibroblasts and vascular endothelial cells (121). The results suggested an angiogenic effect of SP and may explain the abnormal infiltration of pterygium fibroblasts surrounding the damaged Bowman's membrane. In addition, SP has been associated with inflammation via upregulation of pro-inflammatory cytokines (124). Pigment epithelium-derived factor, a well-known angiogenic inhibitor, has been reported to be downregulated in pterygium tissue (125). The imbalance of pro- and anti-angiogenic factors in favor of the former may account for the abundance of blood vessels in pterygia. UV radiation has been demonstrated to induce the synthesis of sensory neuropeptides, including SP (126). Thus, it is reasonable to associate increased SP levels in the tear samples from pterygia patients with UV radiation. However, the differential expression level of other pro- and anti-angiogenic factors in pterygia compared with the normal conjunctiva has not been associated with UV radiation. Further investigation is required to determine the role of UV radiation in the abnormal expression of these effectors.

ECM remodeling. ECM remodeling in the pterygium tissue is exemplified by Bowman's membrane dissolution and elastosis within the pterygia matrix (127). This alteration suggests that pterygium is traditionally a degenerative condition. Using optical microscopy, Bowman's membrane is observed to be abnormally fragmented prior to the formation of fibrovascularized stroma. The degradation of Bowman's membrane has been demonstrated to be closely associated with UV radiation-induced expression of MMPs in PECs and pterygium fibroblasts (85), and their increased expression has been demonstrated in pterygia specimens. The evidence that MMP activity is increased in pterygia, compared with normal conjunctiva, further supports the key roles of MMPs in the dissolution of Bowman's membrane (128). Stromal elastosis was originally considered to be the result of deposits of elastoid degenerative collagen, which is characterized by the appearance of vermiform, coiled and knotty fibers under electron microscopy (129), and amorphous eosinophilic material based on hematoxylin and eosin staining (13). Although elastotic material absorbs elastic stain, it appears to differ from natural elastic tissue, as it remains unaffected by pancreatic elastase.

Elastoid degeneration in the conjunctival portion of pterygia tissue. Pterygia exhibiting a triangular appearance may be divided into two portions designated the corneal and the conjunctival portion, according to the boundary of the limbus. Light and electron microscopic examination demonstrated that elastoid degeneration is commonly observed in the conjunctival portion of pterygia. This degeneration resembles the actinic degenerative change observed in chronic UV radiation-exposed skin. Hogan and Alvarado (130) concluded that the elastotic material is composed of degenerated collagen, pre-existing elastic fibers, fibroblasts with abnormal activity and abnormal ground substance. Based on the observation of collections of amorphous eosinophilic material composed of excess hollow-centered microfibrils (an elastic fiber precursor), Austin et al (131) proposed that the elastotic material in the conjunctival portion of pterygium is formed from newly synthesized elastic fiber precursors and abnormal maturational forms of elastic fibers (elastodysplasia) that undergo secondary degeneration (elastodystrophy). Furthermore, the study suggested that these structures were produced by actinically damaged pterygium fibroblasts (131). Fibroblasts in photo-damaged skin demonstrate increased levels of elastin mRNA compared with the fibroblasts from healthy skin and the elastin induction has been demonstrated to result from the enhanced activity of the elastin promoter (132). These findings indicated that inducible transcription of elastin mRNA in pterygium fibroblasts subsequent to $\mathrm{UV}$ radiation may follow the same mechanism. In animal experiments, a single dose of UVB or UVA radiation (specifically UVB radiation) resulted in increased activity of the elastin promoter in vivo and in vitro in transgenic mice carrying a human elastin promoter (133). Schwartz et al (134) demonstrated that the UV radiation-induced increase in tropo-elastin accumulation was dependent on the post-transcriptional regulation and the accumulation of tropo-elastin was mediated by multiple base substitutions in the non-coding domain of tropo-elastin mRNA rather than increased mRNA synthesis. Wang et al (135) proposed that the increased elastin levels in the pterygium fibroblasts were not a result of the elevated levels of elastin mRNA, but due to the UVB radiation-mediated mutations in the 3'-untranslated region, which alter the translational efficiency of tropo-elastin mRNA in the pterygium fibroblasts. The results from these studies provide further information regarding the potential mechanism underlying the role of UV radiation in pterygia fibroblast-mediated elastoid degeneration.

Degradation of Bowman's membrane. Histological examinations have demonstrated that a severely damaged Bowman's membrane is common at the leading edge of the pterygium $(23,50)$. It is widely accepted that MMPs expressed by PECs and fibroblasts are the predominant cause for this 
Table III. Distribution and expression of MMPs and their inhibitors in pterygia.

UV

First author, year MMPs/TIMPs Distribution in pterygia

Expression inducibility Refs.

\begin{tabular}{|c|c|c|c|c|c|}
\hline $\begin{array}{l}\text { Di Girolamo, } 2004 \\
\text { Di Girolamo, } 2000 \\
\text { Di Girolamo, } 2003\end{array}$ & MMP-1 & Epithelium, fibroblasts & $\uparrow^{\mathrm{a}}$ & Yes & $\begin{array}{c}(23) \\
(85) \\
(147)\end{array}$ \\
\hline $\begin{array}{l}\text { Dushku, } 2001 \\
\text { Zeng, } 2004 \\
\text { Koźák, } 2003\end{array}$ & MMP-2 & Epithelium, inflammatory cells fibroblasts, & $\uparrow^{\mathrm{a}}$ & Yes & $\begin{array}{c}(47) \\
(128) \\
(142)\end{array}$ \\
\hline $\begin{array}{l}\text { Di Girolamo, } 2004 \\
\text { Dushku, 2001 } \\
\text { Brenneisen, } 2002\end{array}$ & MMP-3 & Epithelium, fibroblasts & $\uparrow^{\mathrm{a}}$ & Yes & $\begin{array}{l}(23) \\
(47) \\
(144)\end{array}$ \\
\hline Di Girolamo, 2001 & MMP-7 & Epithelium, vasculature & $\uparrow^{\mathrm{b}}$ & c & $(140)$ \\
\hline Naib-Majani, 2004 & MMP-8 & Epithelium, fibroblasts & d & c & (137) \\
\hline $\begin{array}{l}\text { Tsai, } 2010 \\
\text { Zeng, } 2004 \\
\text { Koźák, } 2003\end{array}$ & MMP-9 & Epithelium, inflammatory cells fibroblasts, vasculature & $\uparrow^{\mathrm{a}}$ & Yes & $\begin{array}{l}(127) \\
(128) \\
(142)\end{array}$ \\
\hline $\begin{array}{l}\text { Tsai, } 2010 \\
\text { Brenneisen, } 2002\end{array}$ & MMP-10 & Epithelium & $\uparrow^{b}$ & Yes & $\begin{array}{l}(127) \\
(144)\end{array}$ \\
\hline Di Girolamo, 2000 & MMP-13 & Epithelium, fibroblasts, vasculature & d & c & $(136)$ \\
\hline Dushku, 2001 & MT1-MMP & Epithelium & $\uparrow^{\mathrm{a}}$ & c & $(47)$ \\
\hline Dushku, 2001 & MT2-MMP & Epithelium & $\uparrow^{\mathrm{a}}$ & $\mathrm{c}$ & (47) \\
\hline $\begin{array}{l}\text { Di Girolamo, } 2000 \\
\text { Di Girolamo, } 2000\end{array}$ & TIMP-1 & Epithelium, fibroblasts & $\uparrow^{\mathrm{b}}$ & No & $\begin{array}{c}(85) \\
(136)\end{array}$ \\
\hline Naib-Majani, 2004 & TIMP-2 & Epithelium, fibroblasts & d & c & $(137)$ \\
\hline $\begin{array}{l}\text { Di Girolamo, } 2000 \\
\text { Di Girolamo, } 2000\end{array}$ & TIMP-3 & Epithelium, inflammatory cells fibroblasts, vasculature & $\uparrow^{b}$ & $\mathrm{c}$ & $\begin{array}{c}(85) \\
(136)\end{array}$ \\
\hline
\end{tabular}

Expression levels of MMPs/TIMPs in pterygia are compared with normal conjunctiva, cornea and limbus. Their UV inducibility is denoted by 'Yes' or 'No'. 'Compared with normal conjunctiva, cornea and limbus; ' ${ }^{\text {a }}$ compared with normal conjunctiva; 'not studied; 'data were not compared with normal conjunctiva, cornea and limbus. MMP, matrix metalloproteinase; MT-MMP, membrane-type MMP; TIMP, tissue inhibitor of MMP; UV, ultraviolet.

change $(85,127,136)$, as that MMPs exhibit proteolytic activity against ECM and components of Bowman's membrane (137). Human MMPs are a family of zinc-dependent endopeptidases, which consists of a minimum of 26 members capable of denaturing the majority of components of ECM. The members are separated into six subgroups based on substrate specificity and homology: Collagenases, gelatinases, stromelysins, matrilysins, membrane-type MMPs (MT-MMPs) and other MMPs (138).

Abnormal expression of MMPs and TIMPs in pterygia and their potential roles in ECM remodeling of pterygia. Previous immunohistochemical studies have described the expression profile of MMPs and TIMPs in pterygium specimens (Table III). These MMPs include MMP-1 (collagenase-1), MMP-13 (collagenase-3), MMP-2 (gelatinase A), MMP-9 (gelatinase B) (136), MMP-3 (stromelysin-1) (139), MMP-10 (stromelysin-2) (127), MMP-7 (matrilysin-1) (140), MMP-8 (137), MT1-MMP, MT2-MMP (47), TIMP-1, TIMP-2 and TIMP-3 (136). A subset of these MMPs, specifically MMP-1 (23,47,85,139), MMP-2 (47,85,128,141), MMP-3 (47), MMP-7 (140), MMP-9 (127,128,141), MMP-10 (127),
MT1-MMP and MT2-MMP (47), and TIMP-1 and TIMP-3 (85), have demonstrated increased expression in pterygium samples, but low or negative expression in normal conjunctiva samples. MMPs have been reported to be preferentially expressed in pterygium epithelium, fibroblasts, leukocytes and endothelium within the pterygium stroma. However, pterygium samples from different patients did not exhibit immunoreactivity for all the above MMPs or TIMPs, and the rate of positive MMP and TIMP expression in pterygia may vary widely in different study groups. This variation may be explained by the use of different methodologies or the examination of various stages of pterygia specimens. The different immunolocalization patterns of MMPs and TIMPs suggest that each factor may serve a specific role in the pathogenesis of pterygium. The pterygium epithelium expresses various MMPs. In particular, a group of pterygium cells in the advancing edge of pterygium, consistently and simultaneously, express elevated MMP-1, MMP-2, MMP-3 and MMP-9, and TIMP-1 and TIMP-2. As elevated expression levels of MMP-2 and MMP-9 are regarded as important in dissolving the basement membrane and adjacent ECM contacts (for example, hemidesmosomes), it may be speculated that the in situ production of these 
MMPs facilitates the pterygium invasion (47). However, pterygium fibroblasts primarily express MMP-1, MMP-3 and MMP-9, which may serve important roles in the dissolution of Bowman's membrane and are likely responsible for the extensive collagen and ECM degradation (139). Normally, to prevent excessive matrix degradation, the expression of TIMPs often parallels that of MMPs. TIMPs act as natural antagonists of MMPs by binding to their latent or active forms. Although elevated expression of TIMP-1, TIMP-2 and TIMP-3 has been observed in pterygium epithelium and fibroblasts, the orchestrated balance is likely disrupted and favors tissue destruction due to the notably increased expression of MMPs. The upregulation of these TIMPs may contribute to the inhibition of the pterygium invasion as Tsai et al (127) demonstrated that elevated TIMP-1 expression decreased the invasion and migration of pterygia. In addition, to being a prototypical inhibitor of the majority of MMP family members, TIMP-1 promotes cell proliferation and inhibits apoptosis by binding to a cell surface complex consisting of CD63 and $\beta-1$ integrin. However, whether TIMP-1 exhibits these activities in pterygia requires further investigation.

The role of $U V$ radiation in the abnormal expression of MMPs and TIMPs in pterygia. Previous studies have demonstrated a potent role of UV radiation in the induction of MMP expression in various cell types, including MMP-2 and MMP-9 in corneal cells (142), MMP-1 and MMP-10 in SCL-1 cells (143), and MMP-1 and MMP-3 in human dermal fibroblasts (144). The promoters of MMP-1, MMP-3 and MMP-9 carry activator protein 1 (AP-1) binding sites, indicating that these genes are transcriptionally regulated by the binding of active AP-1. AP-1 may be activated by UV radiation $(145,146)$, thus, it is hypothesized that UV radiation may be involved in the transcription of a number of MMPs in the pterygium. Di Girolamo et al $(41,147)$ established that the expression of MMP-1, one of the most abundant MMPs in pterygia, is upregulated by UVB radiation in PECs. It was determined that the induction of MMP-1 (collagenase A) by UVB radiation is specifically mediated by ERK1/2 kinase, but not by $\mathrm{p} 38$ or JNK (41,147). Furthermore, MMP-3 has been demonstrated to be induced in PECs following UVB radiation. However, other MMPs and TIMPs, including MMP-2, MMP-9 and TIMP-1, are not induced following UVB radiation (23). Whether the remaining MMPs may be induced by UV radiation has not been demonstrated in pterygium-derived cells. In addition to the classical MAPK signaling pathways, the UV radiation-activated protein kinase $\mathrm{C}$ (PKC) signaling pathway may mediate the upregulation of MMPs. This was demonstrated by the administration of PKC activator TPA, which induced low MMP expression in fibroblasts from early-stage pterygia (141). These findings suggest that UV radiation may be involved in the regulation of MMP expression in pterygia, which is subsequently important in ECM remodeling and invasion in pterygia.

\section{Discussion}

It is well known that the primary subtypes of solar UV rays that reach the earth's surface are UVB and UVA, which are important in human health. Epidemiological studies have demonstrated that UVB and UVA exposure is associated with the development of pterygium. Previous studies on the pathogenesis of pterygia have focused on UVB radiation, which is responsible for the biological effects that have been detected in pterygium samples, including DNA damage, ligand-independent cell surface receptor activation, oxidative stress and intracellular signaling pathway activation. Recently, studies have concentrated on the role of UVA radiation in the pathogenesis of pterygium. The mechanism by which UVA radiation induces damage to the DNA differs from that of UVB radiation. UVA radiation results in indirect damage to cellular DNA via generation of reactive oxygen species. In addition to the damaged DNA, UVA-induced oxidative stress initiates numerous biological effects, including activation of intracellular signaling pathway and transcript factors, which in turn modulate the transcription of multiple targeted genes that involve in ECM remodeling $(148,149)$.

Pterygia is regarded as an ophthalmoheliose triggered by chronic UV damage. As UV radiation results in the induction of diverse biological effects, it provides a good explanation for the pathogenesis of pterygia. Chronic UV radiation specifically damages the nasal limbus as peripheral light focuses in that part of the eye. The damage indicates no clinical abnormality, but it may be effectively detected by UV fluorescence photography (150). It is well established that UV-altered limbal basal epithelial cells is the first step in the initiation of pterygium, however, the precise underlying molecular mechanism remains to be elucidated. UV radiation is known to be mutagenic, and gene mutation has been associated with the formation of pterygium cells. p53 was further investigated as fewer apoptotic markers and squamous metaplasia were detected in pterygia epithelium (151). However, the variability in p53 protein expression indicates that p53 may not be required in the formation of the pterygium cells or the development of pterygia, and suggest that mutations in the p53 pathway or other tumor suppressor genes may be involved in the formation of pterygium cells. Elucidating the mechanism by which UV radiation alters the LSCs is likely to predict the biological behavior of these altered LSCs in pterygium and help to devise appropriate surgical and medical therapeutic strategies. Similarly, UV radiation may alter or activate fibroblasts located in the nasal limbal connective tissue, as these cells receive increased levels of UV radiation compared with other parts of limbus due to limbal light focusing. Although $\mathrm{UV}$ radiation may explain the abnormal biological behavior of fibroblasts in pterygia, the origin of pterygium fibroblasts remains unknown. If UV radiation does contribute to the activation of fibroblasts, the mechanism underlying UV radiation activating the limbal fibroblasts requires investigation and it will be required to determine whether activated fibroblasts are responsible for the excess proliferation of pterygium fibroblasts. Further studies aiming to elucidate the mechanism by which LSCs and fibroblasts evolve into pterygium cells and pterygium fibroblasts are required. Based on the common histopathological changes, including inflammation, neovascularization, elastotic degeneration, Bowman's membrane degradation and fibrous hyperplasia, it is hypothesized that inflammatory cytokines, angiogenic factors, fibrogenic factors and tissue proteolytic enzymes may be involved in the development of pterygium. Previous studies have demonstrated 
increased levels of multiple growth factors, pro-inflammatory cytokines and MMPs in pterygia $(47,75,76)$. The elevated expression of these effectors in pterygium has been attributed to UV radiation, as they were demonstrated to be UV radiation-inducible in pterygium-derived cells in culture or explants in vitro. However, understanding of the detailed underlying mechanisms is limited. Despite the poor understanding of the specific role of various factors in pterygium, based on previous functional studies, it is suggested that the identified factors may contribute to the characteristic histopathologic characteristics of pterygium. Further research is required to elucidate the mechanisms underlying the upregulation of various inflammatory cytokines, growth factors and MMPs in pterygium and their association with UV radiation.

With the continuous depletion of the ozone layer and the elevated UV radiation exposure, the incidence and cost of treatment of pterygium is expected to increase. Therefore, pterygium management is becoming an important public health issue. Preventing the occurrence of pterygium is key, although full protection from sunlight (using conventional sunglasses or hats) is not easily achieved. It is important to develop a usable method to identify individuals particularly at risk of developing pterygia, these individuals at risk could then be advised to take preventive measures, including UV-blocking contact lenses (152) and increased intake of antioxidants in the diet (153). Surgical removal is the only feasible option for the treatment of pterygium, however, postoperative recurrence in certain cases affects success. Thus, to reduce postoperative recurrence of pterygium, surgery combined with adjuvant therapies, including antimetabolites (154), is required. In addition to surgery, a number of types of therapeutic agent have demonstrated potential to inhibit pterygium growth and promote pterygium regression, including growth factor inhibitors (155), antifibrotics (156) and anti-VEGF (157), suggesting that molecular or cellular targeted agents may be the preferred treatment option for pterygium in the future.

\section{Acknowledgements}

The authors would like to thank Shao-Jie Jiang for his assistance in proofreading, and Anyong Xie and Qiaoli Zheng for editing the language in the present review.

\section{References}

1. Chui J, Di Girolamo N, Wakefield D and Coroneo MT: The pathogenesis of pterygium: Current concepts and their therapeutic implications. Ocul Surf 6: 24-43, 2008.

2. Mackenzie FD, Hirst LW, Battistutta D and Green A: Risk analysis in the development of pterygia. Ophthalmology 99: 1056-1061, 1992.

3. Moran DJ and Hollows FC: Pterygium and ultraviolet radiation: A positive correlation. Br J Ophthalmol 68: 343-346, 1984.

4. Cameron ME (ed): Pterygium throughout the world. Charles C Thomas, Springfield IL, 1965.

5. Taylor HR, West SK, Rosenthal FS, Munoz B, Newland HS and Emmett EA: Corneal changes associated with chronic UV irradiation. Arch Ophthalmol 107: 1481-1484, 1989.

6. Detorakis ET, Sourvinos G and Spandidos DA: Detection of herpes simplex virus and human papilloma virus in ophthalmic pterygium. Cornea 20: 164-167, 2001.

7. Gallagher MJ, Giannoudis A, Herrington CS and Hiscott P. Human papillomavirus in pterygium. Br J Ophthalmol 85: 782-784, 2001
8. Chalkia AK, Spandidos DA and Detorakis ET: Viral involvement in the pathogenesis and clinical features of ophthalmic pterygium (Review). Int J Mol Med 32: 539-543, 2013.

9. Anguria P, Kitinya J, Ntuli S and Carmichael T: The role of heredity in pterygium development. Int J Ophthalmol 7: 563-573, 2014.

10. Tsai YY, Bau DT, Chiang CC, Cheng YW, Tseng SH and Tsai FJ: Pterygium and genetic polymorphism of DNA double strand break repair gene Ku70. Mol Vis 13: 1436-1440, 2007.

11. Kau HC, Tsai CC, Hsu WM, Liu JH and Wei YH: Genetic polymorphism of hOGG1 and risk of pterygium in Chinese. Eye (Lond) 18: 635-639, 2004.

12. Pinkerton OD, Hokama Y and Shigemura LA: Immunologic basis for the pathogenesis of pterygium. Am J Ophthalmol 98: 225-228, 1984.

13. Hill JC and Maske R: Pathogenesis of pterygium. Eye (Lond) 3: 218-226, 1989.

14. Coroneo MT: Pterygium as an early indicator of ultraviolet insolation: A hypothesis. Br J Ophthalmol 77: 734-739, 1993.

15. Nubile M, Curcio C, Lanzini M, Calienno R, Iezzi M, Mastropasqua A, Di Nicola M and Mastropasqua L: Expression of CREB in primary pterygium and correlation with cyclin D1, ki-67, MMP7, p53, p63, Survivin and Vimentin. Ophthalmic Res 50: 99-107, 2013.

16. Peng ML, Tsai YY, Chiang CC, Huang YC, Chou MC, Yeh KT, Lee $\mathrm{H}$ and Cheng YW: CYP1A1 protein activity is associated with allelic variation in pterygium tissues and cells. Mol Vis 18: 1937-1943, 2012.

17. Tong L, Li J, Chew J, Tan D and Beuerman R: Phospholipase $\mathrm{D}$ in the human ocular surface and in pterygium. Cornea 27: 693-698, 2008.

18. Ortak H, Cayli S, Ocakli S and Demir S: Increased expression of aquaporin-1 and aquaporin-3 in pterygium. Cornea 32: 1375-1379, 2013.

19. Tan CS, Lim TH, Koh WP, Liew GC, Hoh ST, Tan CC and Au Eong KG: Epidemiology of pterygium on a tropical island in the Riau Archipelago. Eye (Lond) 20: 908-912, 2006.

20. McCarty CA, Fu CL and Taylor HR: Epidemiology of pterygium in Victoria, Australia. Br J Ophthalmol 84: 289-292, 2000.

21. Threlfall TJ and English DR: Sun exposure and pterygium of the eye: A dose-response curve. Am J Ophthalmol 128: 280-287, 1999.

22. Hilgers JH: Pterygium: Its incidence, heredity and etiology. Am J Ophthalmol 50: 635-644, 1960.

23. Di Girolamo N, Chui J, Coroneo MT and Wakefield D: Pathogenesis of pterygia: Role of cytokines, growth factors and matrix metalloproteinases. Prog Retin Eye Res 23: 195-228, 2004.

24. Kwok LS and Coroneo MT: A model for pterygium formation. Cornea 13: 219-224, 1994.

25. Coroneo MT: Albedo concentration in the anterior eye: A phenomenon that locates some solar diseases. Ophthalmic Surg 21: 60-66, 1990.

26. Coroneo MT, Di Girolamo N and Wakefield D: The pathogenesis of pterygia. Curr Opin Ophthalmol 10: 282-288, 1999.

27. Anguria P, Carmichael T, Ntuli S and Kitinya J: Chronic inflammatory cells and damaged limbal cells in pterygium. Afr Health Sci 13: 725-730, 2013

28. Cooper SJ and Bowden GT: Ultraviolet B regulation of transcription factor families: Roles of nuclear factor-kappa $\mathrm{B}$ (NF-kappaB) and activator protein-1 (AP-1) in UVB-induced skin carcinogenesis. Curr Cancer Drug Targets 7: 325-334, 2007.

29. Yajima H, Lee KJ, Zhang S, Kobayashi J and Chen BP: DNA double-strand break formation upon UV-induced replication stress activates ATM and DNA-PKes kinases. J Mol Biol 385: 800-810, 2009

30. Heck DE, Vetrano AM, Mariano TM and Laskin JD: UVB light stimulates production of reactive oxygen species: Unexpected role for catalase. J Biol Chem 278: 22432-22436, 2003.

31. Fisher GJ and Voorhees JJ: Molecular mechanisms of photoaging and its prevention by retinoic acid: Ultraviolet irradiation induces MAP kinase signal transduction cascades that induce Ap-1-regulated matrix metalloproteinases that degrade human skin in vivo. J Investig Dermatol Symp Proc 3: 61-68, 1998.

32. Dy LC, Pei Y and Travers JB: Augmentation of ultraviolet B radiation-induced tumor necrosis factor production by the epidermal platelet-activating factor receptor. J Biol Chem 274: 26917-26921, 1999.

33. Coffer PJ, Burgering BM, Peppelenbosch MP, Bos JL and Kruijer W: UV activation of receptor tyrosine kinase activity. Oncogene 11: 561-569, 1995. 
34. Rosette C and Karin M: Ultraviolet light and osmotic stress: Activation of the JNK cascade through multiple growth factor and cytokine receptors. Science 274: 1194-1197, 1996.

35. Cimpean AM, Sava MP and Raica M: DNA damage in human pterygium: One-shot multiple targets. Mol Vis 19: 348-356, 2013.

36. Lee DH, Cho HJ, Kim JT, Choi JS and Joo CK: Expression of vascular endothelial growth factor and inducible nitric oxide synthase in pterygia. Cornea 20: 738-742, 2001.

37. Kau HC, Tsai CC, Lee CF, Kao SC, Hsu WM, Liu JH and Wei YH: Increased oxidative DNA damage, 8-hydroxydeoxyguanosine, in human pterygium. Eye (Lond) 20: 826-831, 2006.

38. Tsai YY, Cheng YW, Lee H, Tsai FJ, Tseng SH, Lin CL and Chang KC: Oxidative DNA damage in pterygium. Mol Vis 11: 71-75, 2005.

39. Perra MT, Maxia C, Corbu A, Minerba L, Demurtas P, Colombari R, Murtas D, Bravo S, Piras F and Sirigu P: Oxidative stress in pterygium: Relationship between p53 and 8-hydroxydeoxyguanosine. Mol Vis 12: 1136-1142, 2006.

40. Klebe S, Callahan T and Power JH: Peroxiredoxin I and II in human eyes: Cellular distribution and association with pterygium and DNA damage. J Histochem Cytochem 62: 85-96, 2014.

41. Di Girolamo N, Coroneo M and Wakefield D: Epidermal growth factor receptor signaling is partially responsible for the increased matrix metalloproteinase-1 expression in ocular epithelial cells after UVB radiation. Am J Pathol 167: 489-503, 2005.

42. Di Girolamo N, Wakefield D and Coroneo MT: UVB-mediated induction of cytokines and growth factors in pterygium epithelial cells involves cell surface receptors and intracellular signaling. Invest Ophthalmol Vis Sci 47: 2430-2437, 2006.

43. Dushku N and Reid TW: Immunohistochemical evidence that human pterygia originate from an invasion of vimentin-expressing altered limbal epithelial basal cells. Curr Eye Res 13: 473-481, 1994.

44. Davanger M and Evensen A: Role of the pericorneal papillary structure in renewal of corneal epithelium. Nature 229: 560-561, 1971.

45. Tseng SCG CJ, Huang AJW, Kruse FE, Maskin SL and Tsai RJF: Classification of conjunctival surgeries for corneal diseases based on stem cell concept. Ophthalmol Clin North Am 3: 595-610, 1990.

46. Reid TW and Dushku N: What a study of pterygia teaches us about the cornea? Molecular mechanisms of formation. Eye Contact Lens 36: 290-295, 2010.

47. Dushku N, John MK, Schultz GS and Reid TW: Pterygia pathogenesis: Corneal invasion by matrix metalloproteinase expressing altered limbal epithelial basal cells. Arch Ophthalmol 119: 695-706, 2001.

48. Reid TW and Dushku N: Pterygia and limbal epithelial cells: Relationship and molecular mechanisms. Prog Retin Eye Res 15(2): 297-329, 1996.

49. Jaworski CJ, Aryankalayil-John M, Campos MM, Fariss RN, Rowsey J, Agarwalla N, Reid TW, Dushku N, Cox CA, Carper D and Wistow G: Expression analysis of human pterygium shows a predominance of conjunctival and limbal markers and genes associated with cell migration. Mol Vis 15: 2421-2434, 2009.

50. Chui J, Coroneo MT, Tat LT, Crouch R, Wakefield D and Di Girolamo N: Ophthalmic pterygium: A stem cell disorder with premalignant features. Am J Pathol 178: 817-827, 2011.

51. Fuchs E. Ueber das Pterygium [Concerning the pterygium]. Graefes Arch Ophthalmol 38: 1-89, 1892 (In German).

52. Hoover HL: Solar ultraviolet irradiation of human cornea, lens and retina: Equations of ocular irradiation. Appl Opt 25: 359-368, 1986.

53. Brash DE, Rudolph JA, Simon JA, Lin A, McKenna GJ, Baden HP, Halperin AJ and Pontén J: A role for sunlight in skin cancer: UV-induced p53 mutations in squamous cell carcinoma. Proc Natl Acad Sci USA 88: 10124-10128, 1991.

54. Kress S, Sutter C, Strickland PT, Mukhtar H, Schweizer J and Schwarz M: Carcinogen-specific mutational pattern in the p53 gene in ultraviolet $\mathrm{B}$ radiation-induced squamous cell carcinomas of mouse skin. Cancer Res 52: 6400-6403, 1992

55. Ziegler A, Leffell DJ, Kunala S, Sharma HW, Gailani M, Simon JA, Halperin AJ, Baden HP, Shapiro PE, Bale AE, et al: Mutation hotspots due to sunlight in the p53 gene of nonmelanoma skin cancers. Proc Natl Acad Sci USA 90: 4216-4220, 1993.

56. Finlay CA, Hinds PW, Tan TH, Eliyahu D, Oren M and Levine AJ: Activating mutations for transformation by p53 produce a gene product that forms an hsc70-p53 complex with an altered half-life. Mol Cell Biol 8: 531-539, 1988.
57. Dushku N and Reid TW: P53 expression in altered limbal basal cells of pingueculae, pterygia and limbal tumors. Curr Eye Res 16: 1179-1192, 1997.

58. Tan DT, Lim AS, Goh HS and Smith DR: Abnormal expression of the p53 tumor suppressor gene in the conjunctiva of patients with pterygium. Am J Ophthalmol 123: 404-405, 1997.

59. Weinstein O, Rosenthal G, Zirkin H, Monos T, Lifshitz T and Argov S: Overexpression of p53 tumor suppressor gene in pterygia. Eye (Lond) 16: 619-621, 2002.

60. Ueda Y, Kanazawa S, Kitaoka T, Dake Y, Ohira A, Ouertani AM and Amemiya T: Immunohistochemical study of p53, p21 and PCNA in pterygium. Acta Histochem 103: 159-165, 2001.

61. Tsai YY, Cheng YW, Lee H, Tsai FJ, Tseng SH and Chang KC: P53 gene mutation spectrum and the relationship between gene mutation and protein levels in pterygium. Mol Vis 11: 50-55, 2005.

62. Reisman D, McFadden JW and Lu G: Loss of heterozygosity and p53 expression in Pterygium. Cancer Lett 206: 77-83, 2004.

63. Shimmura S, Ishioka M, Hanada K, Shimazaki J and Tsubota K: Telomerase activity and p53 expression in pterygia. Invest Ophthalmol Vis Sci 41: 1364-1369, 2000.

64. Chen JK, Tsai RJ and Lin SS: Fibroblasts isolated from human pterygia exhibit transformed cell characteristics. In Vitro Cell Dev Biol Anim 30A: 243-248, 1994.

65. Cameron ME: Histology of pterygium: An electron microscopic study. Br J Ophthalmol 67: 604-608, 1983.

66. Lemercier G, Cornand G and Burckhart MF: Pinguecula and pterygium: Histologic and electron microscopic study (author's transl). Virchows Arch A Pathol Anat Histol 379: 321-333, 1978 (In French).

67. Ye J, Song YS, Kang SH, Yao K and Kim JC: Involvement of bone marrow-derived stem and progenitor cells in the pathogenesis of pterygium. Eye (Lond) 18: 839-843, 2004.

68. Touhami A, Di Pascuale MA, Kawatika T, Del Valle M, Rosa RH Jr, Dubovy S and Tseng SC. Characterisation of myofibroblasts in fibrovascular tissues of primary and recurrent pterygia. Br J Ophthalmol 89: 269-274, 2005.

69. Kato N, Shimmura S, Kawakita T, Miyashita H, Ogawa Y, Yoshida S, Higa K, Okano H and Tsubota K: Beta-catenin activation and epithelial-mesenchymal transition in the pathogenesis of pterygium. Invest Ophthalmol Vis Sci 48: 1511-1517, 2007.

70. Maloof AJ, Ho A and Coroneo MT: Influence of corneal shape on limbal light focusing. Invest Ophthalmol Vis Sci 35: 2592-2598, 1994.

71. Butrus SI, Ashraf MF, Laby DM, Rabinowitz AI, Tabbara SO and Hidayat AA: Increased numbers of mast cells in pterygia. Am J Ophthalmol 119: 236-237, 1995.

72. Ratnakar KS, Goswamy V and Agarwal LP: Mast cells and pterygium. Acta Ophthalmol (Copenh) 54: 363-368, 1976.

73. Golu T, Mogoantă L, Streba CT, Pirici DN, Mălăescu D, Mateescu GO and Mutiu G: Pterygium: Histological and immunohistochemical aspects. Rom J Morphol Embryol 52: 153-158, 2011.

74. Wen Z and Liu Z: The abnormal expression of interleukine-1 family in pterygium. Yan Ke Xue Bao 19: 133-136, 2003.

75. Di Girolamo N, Kumar RK, Coroneo MT and Wakefield D: UVB-mediated induction of interleukin- 6 and -8 in pterygia and cultured human pterygium epithelial cells. Invest Ophthalmol Vis Sci 43: 3430-3437, 2002.

76. Kria L, Ohira A and Amemiya T: Immunohistochemical localization of basic fibroblast growth factor, platelet derived growth factor, transforming growth factor-beta and tumor necrosis factor-alpha in the pterygium. Acta Histochem 98: 195-201, 1996.

77. Kennedy M, Kim KH, Harten B, Brown J, Planck S, Meshul C, Edelhauser H, Rosenbaum JT, Armstrong CA and Ansel JC: Ultraviolet irradiation induces the production of multiple cytokines by human corneal cells. Invest Ophthalmol Vis Sci 38: 2483-2491, 1997.

78. Krämer M, Sachsenmaier C, Herrlich P and Rahmsdorf HJ: UV irradiation-induced interleukin-1 and basic fibroblast growth factor synthesis and release mediate part of the UV response. J Biol Chem 268: 6734-6741, 1993.

79. Bazzoni F, Kruys V, Shakhov A, Jongeneel CV and Beutler B. Analysis of tumor necrosis factor promoter responses to ultraviolet light. J Clin Invest 93: 56-62, 1994.

80. Devary Y, Rosette C, DiDonato JA and Karin M: NF-kappa B activation by ultraviolet light not dependent on a nuclear signal. Science 261: 1442-1445, 1993.

81. Siak JJ, Ng SL, Seet LF, Beuerman RW and Tong L: The nuclear-factor kappaB pathway is activated in pterygium. Invest Ophthalmol Vis Sci 52: 230-236, 2011. 
82. Cubitt CL, Tang Q, Monteiro CA, Lausch RN and Oakes JE: IL-8 gene expression in cultures of human corneal epithelial cells and keratocytes. Invest Ophthalmol Vis Sci 34: 3199-3206, 1993

83. Cubitt CL, Lausch RN and Oakes JE: Differences in interleukin-6 gene expression between cultured human corneal epithelial cells and keratocytes. Invest Ophthalmol Vis Sci 36 330-336, 1995.

84. Hong JW, Liu JJ, Lee JS, Mohan RR, Mohan RR, Woods DJ, $\mathrm{He}$ YG and Wilson SE: Proinflammatory chemokine induction in keratocytes and inflammatory cell infiltration into the cornea. Invest Ophthalmol Vis Sci 42: 2795-2803, 2001

85. Di Girolamo N, McCluskey P, Lloyd A, Coroneo MT and Wakefield D: Expression of MMPs and TIMPs in human pterygia and cultured pterygium epithelial cells. Invest Ophthalmol Vis Sci 41: 671-679, 2000.

86. Fenton RR, Molesworth-Kenyon S, Oakes JE and Lausch RN: Linkage of IL-6 with neutrophil chemoattractant expression in virus-induced ocular inflammation. Invest Ophthalmol Vis Sci 43: 737-743, 2002.

87. Cohen T, Nahari D, Cerem LW, Neufeld G and Levi BZ: Interleukin 6 induces the expression of vascular endothelia growth factor. J Biol Chem 271: 736-741, 1996.

88. Bacon KB and Camp RD: Interleukin (IL)-8-induced in vitro human lymphocyte migration is inhibited by cholera and pertussis toxins and inhibitors of protein kinase C. Biochem Biophys Res Commun 169: 1099-1104, 1990.

89. Roebuck KA: Regulation of interleukin-8 gene expression. J Interferon Cytokine Res 19: 429-438, 1999.

90. Strieter RM, Kunkel SL, Elner VM, Martonyi CL, Koch AE, Polverini PJ and Elner SG: Interleukin-8. A corneal factor that induces neovascularization. Am J Pathol 141: 1279-1284, 1992.

91. Starcher B: Role for tumour necrosis factor-alpha receptors in ultraviolet-induced skin tumours. Br J Dermatol 142: 1140-1147, 2000.

92. Yoshida S, Ono M, Shono T, Izumi H, Ishibashi T, Suzuki H and Kuwano M: Involvement of interleukin-8, vascular endothelial grow th factor, and basic fibroblast growth factor in tumor necrosis factor alpha-dependent angiogenesis. Mol Cell Biol 17: 4015-4023, 1997

93. Menzel EJ, Egerer I, Kulnig $W$ and Smolen JS : Electron-microscopic and biochemical characteristics of pterygia (author's transl). Klin Monbl Augenheilkd 179: 438-441, 1981 (In German).

94. Dake Y, Mukae R, Soda Y, Kaneko M and Amemiya T: Immunohistochemical localization of collagen types I, II, III and IV in pterygium tissues. Acta Histochem 87: 71-74, 1989.

95. Nolan TM, Di Girolamo N, Sachdev NH, Hampartzoumian T, Coroneo MT and Wakefield D: The role of ultraviolet irradiation and heparin-binding epidermal growth factor-like growth factor in the pathogenesis of pterygium. Am J Pathol 162: 567-574, 2003

96. Bianchi E, Scarinci F, Grande C, Plateroti R, Plateroti P, Plateroti AM, Fumagalli L, Capozzi P, Feher J and Artico M: Immunohistochemical profile of VEGF, TGF- $\beta$ and PGE $_{2}$ in human pterygium and normal conjunctiva: Experimental study and review of the literature. Int J Immunopathol Pharmacol 25 : 607-615, 2012

97. Liu Z, Xie Y and Zhang M: Overexpression of type I growth factor receptors in pterygium. Chin Med J (Engl) 115: 418-421, 2002

98. Detorakis ET and Spandidos DA: Pathogenetic mechanisms and treatment options for ophthalmic pterygium: Trends and perspectives (Review). Int J Mol Med 23: 439-447, 2009

99. Krial L, Ohira A and Amemiya T: Growth factors in cultured pterygium fibroblasts: Immunohistochemical and ELISA analysis. Graefes Arch Clin Exp Ophthalmol 236: 702-708, 1998.

100.Li Y, Bi Z, Yan B and Wan Y: UVB radiation induces expression of HIF-1alpha and VEGF through the EGFR/PI3K/DEC1 pathway. Int J Mol Med 18: 713-719, 2006

101. Kim H, Kang JS and Lee WJ: The production IL-21 and VEGF in UVB-irradiated human keratinocyte cell line, HaCaT. Immune Netw 10: 75-80, 2010.

102. Brauchle M, Funk JO, Kind P and Werner S: Ultraviolet B and $\mathrm{H} 2 \mathrm{O} 2$ are potent inducers of vascular endothelial growth factor expression in cultured keratinocytes. J Biol Chem 271: 21793-21797, 1996.

103. Ley RD, Miska KB and Kusewitt DF: Photoreactivation of ultraviolet radiation-induced basic fibroblast growth factor (bFGF) and the role of bFGF in corneal lesion formation in Monodelphis domestica. Environ Mol Mutagen 38: 175-179, 2001.
104. Brenner M, Degitz K, Besch R and Berking C: Differential expression of melanoma-associated growth factors in keratinocytes and fibroblasts by ultraviolet $\mathrm{A}$ and ultraviolet $\mathrm{B}$ radiation. Br J Dermatol 153: 733-739, 2005.

105. Quan T, He T, Kang S, Voorhees JJ and Fisher GJ: Ultraviolet irradiation alters transforming growth factor beta/smad pathway in human skin in vivo. J Invest Dermatol 119: 499-506, 2002.

106. Xu D, Yuan R, Gu H, Liu T, Tu Y, Yang Z and He L: The effect of ultraviolet radiation on the transforming growth factor beta $1 /$ Smads pathway and p53 in actinic keratosis and normal skin. Arch Dermatol Res 305: 777-786, 2013

107. Abramovitch R, Neeman M, Reich R, Stein I, Keshet E, Abraham J, Solomon A and Marikovsky M: Intercellular communication between vascular smooth muscle and endothelial cells mediated by heparin-binding epidermal growth factor-like growth factor and vascular endothelial growth factor. FEBS Lett 425: 441-447, 1998

108. Harding PA, Davis-Fleischer KM, Crissman-Combs MA, Miller MT, Brigstock DR and Besner GE: Induction of anchorage independent growth by heparin-binding EGF-like growth factor (HB-EGF). Growth Factors 17: 49-61, 1999.

109. Nolan TM, Di Girolamo N, Coroneo MT and Wakefield D: Proliferative effects of heparin-binding epidermal growth factor-like growth factor on pterygium epithelial cells and fibroblasts. Invest Ophthalmol Vis Sci 45: 110-113, 2004.

110. Witmer AN, Vrensen GF, Van Noorden CJ and Schlingemann RO: Vascular endothelial growth factors and angiogenesis in eye disease. Prog Retin Eye Res 22: 1-29, 2003.

111. Andresen JL and Ehlers N: Chemotaxis of human keratocytes is increased by platelet-derived growth factor-BB, epidermal growth factor, transforming growth factor-alpha, acidic fibroblast growth factor, insulin-like growth factor-I, and transforming growth factor-beta. Curr Eye Res 17: 79-87, 1998.

112. Fredj-Reygrobellet D, Plouet J, Delayre T, Baudouin C, Bourret F and Lapalus P: Effects of aFGF and bFGF on wound healing in rabbit corneas. Curr Eye Res 6: 1205-1209, 1987.

113. Nugent MA and Iozzo RV: Fibroblast growth factor-2. Int J Biochem Cell Biol 32: 115-120, 2000.

114. Govinden R and Bhoola KD: Genealogy, expression, and cellular function of transforming growth factor-beta. Pharmacol Ther 98: 257-265, 2003.

115. Roberts AB, Sporn MB, Assoian RK, Smith JM, Roche NS, Wakefield LM, Heine UI, Liotta LA, Falanga V, Kehrl JH, et al: Transforming growth factor type beta: Rapid induction of fibrosis and angiogenesis in vivo and stimulation of collagen formation in vitro. Proc Natl Acad Sci USA 83: 4167-4171, 1986.

116. Verrecchia $F$ and Mauviel A: Transforming growth factor-beta and fibrosis. World J Gastroenterol 13: 3056-3062, 2007.

117. Dushku N and Reid TW: Immunohistochemical evidence that pterygia originate from Rb and TGF-beta expressing, p53 transformed, limbal basal stem cells. Invest Ophthalmol Vis Sci 36: S1027, 1995.

118. Oikawa T, Onozawa C, Sakaguchi M, Morita I and Murota S: Three isoforms of platelet-derived growth factors all have the capability to induce angiogenesis in vivo. Biol Pharm Bull 17: 1686-1688, 1994

119. Kamiyama K, Iguchi I, Wang X and Imanishi J: Effects of PDGF on the migration of rabbit corneal fibroblasts and epithelial cells. Cornea 17: 315-325, 1998.

120. Aspiotis M, Tsanou E, Gorezis S, Ioachim E, Skyrlas A, Stefaniotou M and Malamou-Mitsi V: Angiogenesis in pterygium: Study of microvessel density, vascular endothelial growth factor, and thrombospondin-1. Eye (Lond) 21: 1095-1101, 2007.

121. Chui J, Di Girolamo N, Coroneo MT and Wakefield D: The role of substance $\mathrm{P}$ in the pathogenesis of pterygia. Invest Ophthalmol Vis Sci 48: 4482-4489, 2007.

122. Naib-Majani W, Breipohl W, Shazli EE, Theuerkauf I, Pleyer U, Hahne JC and Wernert N: The Ets-1 transcription factor is involved in pterygial angiogenesis. Anat Histol Embryol 36: $107-110,2007$

123. Lee JK, Song YS, Ha HS, Park JH, Kim MK, Park AJ and Kim JC: Endothelial progenitor cells in pterygium pathogenesis. Eye (Lond) 21: 1186-1193, 2007.

124. Tran MT, Lausch RN and Oakes JE: Substance P differentially stimulates IL-8 synthesis in human corneal epithelial cells. Invest Ophthalmol Vis Sci 41: 3871-3877, 2000

125. Jin J, Guan M, Sima J, Gao G, Zhang M, Liu Z, Fant J and Ma JX: Decreased pigment epithelium-derived factor and increased vascular endothelial growth factor levels in pterygia. Cornea 22: 473-477, 2003. 
126. Legat FJ, Griesbacher T, Schicho R, Althuber P, Schuligoi R, Kerl $\mathrm{H}$ and Wolf P: Repeated subinflammatory ultraviolet B irradiation increases substance $\mathrm{P}$ and calcitonin gene-related peptide content and augments mustard oil-induced neurogenic inflammation in the skin of rats. Neurosci Lett 329: 309-313, 2002

127. Tsai YY, Chiang CC, Yeh KT, Lee H and Cheng YW: Effect of TIMP-1 and MMP in pterygium invasion. Invest Ophthalmol Vis Sci 51: 3462-3467, 2010.

128.Zeng J, Jiang D, Liu X and Tang L: Expression of matrix metalloproteinase in human pterygia. Yan Ke Xue Bao 20: 242-245, 2004 (In Chinese)

129. Ansari MW, Rahi AH and Shukla BR: Pseudoelastic nature of pterygium. Br J Ophthalmol 54: 473-476, 1970.

130. Hogan MJ and Alvarado J: Pterygium and pinguecula: Electron microscopic study. Arch Ophthalmol 78: 174-186, 1967.

131. Austin P, Jakobiec FA and Iwamoto T: Elastodysplasia and elastodystrophy as the pathologic bases of ocular pterygia and pinguecula. Ophthalmology 90: 96-109, 1983.

132.Bernstein EF, Chen YQ, Tamai K, Shepley KJ, Resnik KS Zhang H, Tuan R, Mauviel A and Uitto J: Enhanced elastin and fibrillin gene expression in chronically photodamaged skin. J Invest Dermatol 103: 182-186, 1994.

133. Bernstein EF, Brown DB, Urbach F, Forbes D, Del Monaco M, Wu M, Katchman SD and Uitto J: Ultraviolet radiation activates the human elastin promoter in transgenic mice: A novel in vivo and in vitro model of cutaneous photoaging. J Invest Dermatol 105: 269-273, 1995.

134. Schwartz E, Feinberg E, Lebwohl M, Mariani TJ and Boyd CD: Ultraviolet radiation increases tropoelastin accumulation by a post-transcriptional mechanism in dermal fibroblasts. J Inves Dermatol 105: 65-69, 1995.

135. Wang IJ, Hu FR, Chen PJ and Lin CT: Mechanism of abnormal elastin gene expression in the pinguecular part of pterygia. Am J Pathol 157: 1269-1276, 2000.

136. Di Girolamo N, Wakefield D and Coroneo MT: Differential expression of matrix metalloproteinases and their tissue inhibitors at the advancing pterygium head. Invest Ophthalmo Vis Sci 41: 4142-4149, 2000.

137. Naib-Majani W, Eltohami I, Wernert N, Watts W, Tschesche H, Pleyer U and Breipohl W: Distribution of extracellular matrix proteins in pterygia: An immunohistochemical study. Graefes Arch Clin Exp Ophthalmol 242: 332-338, 2004.

138. Sekhon BS: Matrix metalloproteinases - an overview. Res Rep Biol 1: 1-20, 2010

139.Li DQ, Lee SB, Gunja-Smith Z, Liu Y, Solomon A, Meller D and Tseng SC: Overexpression of collagenase (MMP-1) and stromelysin (MMP-3) by pterygium head fibroblasts. Arch Ophthalmol 119: 71-80, 2001.

140. Di Girolamo N, Coroneo MT and Wakefield D: Active matrilysin (MMP-7) in human pterygia: Potential role in angiogenesis. Invest Ophthalmol Vis Sci 42: 1963-1968, 2001.

141. Yang SF, Lin CY, Yang PY, Chao SC, Ye YZ and Hu DN: Increased expression of gelatinase (MMP-2 and MMP-9) in pterygia and pterygium fibroblasts with disease progression and activation of protein kinase C. Invest Ophthalmol Vis Sci 50 4588-4596, 2009.
142. Koźák I, Klisenbauer D and Juhás T: UV-B induced production of MMP-2 and MMP-9 in human corneal cells. Physiol Res 52: 229-234, 2003.

143. Ramos MC, Steinbrenner H, Stuhlmann D, Sies H and Brenneisen P: Induction of MMP-10 and MMP-1 in a squamous cell carcinoma cell line by ultraviolet radiation. Biol Chem 385 75-86, 2004.

144.Brenneisen $P$, Sies $H$ and Scharffetter-Kochanek K Ultraviolet-B irradiation and matrix metalloproteinases: From induction via signaling to initial events. Ann N Y Acad Sci 973: 31-43, 2002.

145. Stein B, Rahmsdorf HJ, Steffen A, Litfin M and Herrlich P: UV-induced DNA damage is an intermediate step in UV-induced expression of human immunodeficiency virus type 1, collagenase, c-fos, and metallothionein. Mol Cell Biol 9: 5169-5181, 1989.

146. Rittié L and Fisher GJ: UV-light-induced signal cascades and skin aging. Ageing Res Rev 1: 705-720, 2002.

147. Di Girolamo N, Coroneo MT and Wakefield D: UVB-elicited induction of MMP-1 expressionin human ocular surface epithelial cells is mediated through the ERK1/2 MAPK-dependent pathway. Invest Ophthalmol Vis Sci 44: 4705-4714, 2003.

148. Bachelor MA and Bowden GT: UVA-mediated activation of signaling pathways involved in skin tumor promotion and progression. Semin Cancer Biol 14: 131-138, 2004.

149. Chao SC, Hu DN, Yang PY, Lin CY, Nien CW, Yang SF and Robert JE: Ultraviolet-A irradiation upregulated urokinase-type plasminogen activator in pterygium fibroblasts through ERK and JNK pathways. Invest Ophthalmol Vis Sci 54: 999-1007, 2013.

150. Ooi JL, Sharma NS, Papalkar D, Sharma S, Oakey M, Dawes P and Coroneo MT: Ultraviolet fluorescence photography to detect early sun damage in the eyes of school-aged children. Am J Ophthalmol 141: 294-298, 2006.

151. Tan DT, Tang WY, Liu YP, Goh HS and Smith DR: Apoptosis and apoptosis related gene expression in normal conjunctiva and pterygium. Br J Ophthalmol 84: 212-226, 2000

152. Kwok LS, Kuznetsov VA, Ho A and Coroneo MT: Prevention of the adverse photic effects of peripheral light-focusing using UV-blocking contact lenses. Invest Ophthalmol Vis Sci 44 1501-1507, 2003.

153. Coroneo M: Ultraviolet radiation and the anterior eye. Eye Contact Lens 37: 214-224, 2011.

154. Said DG, Faraj LA, Elalfy MS, Yeung A, Miri A, Fares U, Otri AM, Rahman I, Maharajan S and Dua HS: Intra-lesional 5 fluorouracil for the management of recurrent pterygium. Eye (Lond) 27: 1123-1129, 2013.

155. Cuevas P, Outeiriño LA, Angulo J and Giménez-Gallego G: Topical dobesilate eye drops for ophthalmic primary pterygium. BMJ Case Rep, 2012.

156. Lee K, Young Lee S, Park SY and Yang H: Antifibrotic effect of pirfenidone on human pterygium fibroblasts. Curr Eye Res 39: 680-685, 2014

157. Sarac O, Demirel S and Oltulu R: Efficacy of intralesional bevacizumab administration in primary pterygium: A quantitative analysis. Eye Contact Lens 40: 46-50, 2014. 